\title{
Tabung Haji: Public Concern and Future Direction
}

\author{
Mohammad Mahbubi Ali* \\ Nur Amalina Abdul Ghani**
}

The organisation of pilgrimage welfare in Malaysia traces back to the Sultanate of Malacca in the $15^{\text {th }}$ century, as recorded in the classical Malay text, Hikayat Hang Tuah. In modern times, the Muslim Pilgrim Ordinance was launched in 1951 by the British administration to oversee the welfare of pilgrims. Among the primary areas in which the ordinance wished to assist were the financial management and preparation by pilgrims before they depart to Mecca, in addition to funeral arrangements for pilgrims who passed away while travelling.

Based on the idea of Ungku Abdul Aziz bin Ungku Abdul Hamid, a renowned Malay economist and Royal Professor, the Malaysian Parliament established the Malayan Muslim Pilgrims Savings Corporation in August of 1962, under Parliament Act No. 34. The corporation was initially established to pioneer a shariah-compliant investment vehicle to help Malayan Muslims perform the last pillar of Islam and manage their funds in a shariah-compliant manner.

In 1969, the name of the corporation was changed to Tabung Haji (TH) and placed under the revised Malaysian Law Act 8 in 1973, which was again superseded by Act 535 in 1995, due to public concern over the structure and responsibilities of $\mathrm{TH}$ in dealing with the increasing number of deaths among Malaysian Muslim pilgrimages.

\section{Performance and Public Concern}

TH started its operation in 1963 with a total fund collection of RM43,680 from 1281 Muslims depositors. In 2018, TH recorded RM 75.5 billion funds received from over 9.3 million Muslim depositors, making TH the world's biggest Islamic fund.

However, the recent announcement of the 2018 hibah (dividend) declaration at $1.25 \%$, the lowest since 1995 , has triggered public tension, especially among depositors. Depositors began to compare the performance of TH under the previous administration where $\mathrm{TH}$ successfully distributed hibah to its depositors of between $3.25 \%$ and $9.5 \%$ from 1995 until 2017 . 
The newly appointed CEO of TH, Datuk Seri Zukri Samat has tabled a big plan to save the fund by setting up a Special Purpose Vehicle, named Urusharta Jemaah Sdn Bhd, and transferring underperforming stakes in listed companies and other assets, such as Tun Razak Exchange, at an agreed valuation.

Again, the plan sparked public anger when a non-Muslim was appointed the CEO of Prokhas Sdn Bhd, another government-owned SPV that administers the assets temporarily, although all the directors of Prokhas are Muslims. It is believed that this situation is not in line with the spirit of Section 6 of the Tabung Haji 1995 (Act 535), where no person shall be appointed member of the Lembaga (Board) unless he is a Muslim and Malaysian citizen. Additionally, there is no evidence that a shariah committee has been adequately established within many SPVs or how the said SPV fully assures the shariah-compliance of investments.

Apart from that, public concerns have also arisen over the status of 106 strategic companies involved in the transferring of assets, such as UEM Sunrise Bhd, Boustead Heavy Industries Corp Bhd, Puncak Niaga Holdings Bhd, Brahim's Holding Bhd, MMC Corp Bhd, and Mah Sing Group Bhd. The Auditor General and an appointed external auditor, i.e. PricewaterhouseCoopers (PwC) discovered that the paper loss suffered by TH was due to equity investment valued up to RM10 billion as at 31 December 2018. The new management of $\mathrm{TH}$, however, is convinced that the turnaround plan would place TH in a better position by 2019 .

\section{Transparency \& Good Governance}

TH's existing indicative rate or promise also raises concern over the concept of Islamic contract between the depositors and the Fund, which is based on wadhiah yad dhamanah (safekeeping with guarantee) and hibah (unilateral complimentary contract). Section 16 of Tabung Haji Act 1995 (Act 535) states that deposits should be received by the Lembaga for the following purposes:

1. Saving towards the pilgrimage of the individual to the Holy Land; or

2. Savings for investment or any other purpose permitted by the Lembaga.

Section 22 of the same Act also mentions that "the Lembaga may at its absolute discretion determine at any time whether it is prudent to declare a sum as distributable profit in respect of any particular period".

However, the official website of TH cites otherwise;

It is a savings concept where depositors save their monies and $\mathrm{TH}$ as the custodian agrees to safeguard the monies. In this contract, depositors give consent to $\mathrm{TH}$ to use/ borrow their monies for business, 
investments, etc. TH/ the Government will guarantee the monies placed under their custody. As far as profits are concerned, profits earned are wholly owned by $\mathrm{TH}$. Therefore, profits and other returns distributed to depositors are at the discretion of $\mathrm{TH}$.

The word "profit" in the Act contradicts the concept of wadhiah yad dhamanah, where no profit is expected at any point from the property or monies lent to the borrower, TH. Therefore, the creation of SPV by the new management, resulting in the increasing value of assets up to RM10 billion to cover the paper loss in 2018, is deemed unnecessary. This is because hibah should not be declared in the first place under the Act.

\section{Moving Forward}

If the case remains as required by the Act, a full overhaul can be suggested within the Fund to ensure transparency and good governance. This includes limiting the power of the Minister in appointing the Chairman and seven other members of the Lembaga and approving the investment avenues for the depositors' monies. This could further eliminate any political agenda and conflict of interest.

Apart from that, the auditor of the Fund must be completely independent. This is due to the significant concern raised by the public over the different opinions sighted by the Lembaga and its members that have a significant influence on the selection of the external auditor. The best solution to this is to limit the authority of the Lembaga or its management in the appoint of an auditor.

Accordingly, a national authority body that reports directly to the Yang Dipertuan Agong is suggested to select and appoint competent members of the Lembaga, qualified and independent auditors, and to decide on the investment avenues of the Lembaga. The Parliament's Public Accountability Committee should also be given a right to undertake a check and balance on the expenses of performing Hajj.

An amendment to the Tabung Haji Act 1995 is also required. The second Pilgrims Economic Welfare Committee Report should be discussed among the stakeholders and re-tabled in the Parliament to reflect the significant changes that have taken place in the 55 years since the inception of the Pilgrims' Savings Corporation in 1963. 


\section{Notes}

* Mohammad Mahbubi Ali is Research Fellow, International Institute of Advanced Islamic Studies (IAIS) Malaysia.

** Nur Amalina Abdul Ghani read law at Ahmad Ibrahim Kuliyyah of Law, IIUM (Malaysia) and completed an LLB and LLM from the same University. She holds a $\mathrm{PhD}$ in Islamic finance from the University of Bolton, UK. Nur Amalina is currently a practicing partner at Messrs Amalina \& Associates specialising in conveyancing, anti money laundering, commercial, and Islamic finance law and policy. 